\title{
Chemical vapour deposition of chromium-doped tungsten disulphide thin films on glass and steel substrates from molecular precursors
}

DOI:

10.1039/c8tc01991f

\section{Document Version}

Accepted author manuscript

Link to publication record in Manchester Research Explorer

Citation for published version (APA):

Murtaza, G., Venkateswaran, S. P., Thomas, A. G., O'Brien, P., \& Lewis, D. J. (2018). Chemical vapour deposition of chromium-doped tungsten disulphide thin films on glass and steel substrates from molecular precursors. Journal of Materials Chemistry C, 6(35), 9537-9544. https://doi.org/10.1039/c8tc01991f

Published in:

Journal of Materials Chemistry C

\section{Citing this paper}

Please note that where the full-text provided on Manchester Research Explorer is the Author Accepted Manuscript or Proof version this may differ from the final Published version. If citing, it is advised that you check and use the publisher's definitive version.

\section{General rights}

Copyright and moral rights for the publications made accessible in the Research Explorer are retained by the authors and/or other copyright owners and it is a condition of accessing publications that users recognise and abide by the legal requirements associated with these rights.

\section{Takedown policy}

If you believe that this document breaches copyright please refer to the University of Manchester's Takedown Procedures [http://man.ac.uk/04Y6Bo] or contact uml.scholarlycommunications@manchester.ac.uk providing relevant details, so we can investigate your claim.

\section{OPEN ACCESS}




\title{
Journal of Materials Chemistry C
}

\section{ARTICLE}

Received 00th January 20xx, Accepted 00th January 20xx DOI: $10.1039 / x 0 x \times 00000 x$ www.rsc.org/

\section{Chemical vapour deposition of chromium-doped tungsten disulphide thin films on glass and steel substrate from molecular precursors}

\author{
Ghulam Murtaza, $^{\text {a c }}$ Sai P. Venkateswaran, ${ }^{d}$ Andrew G. Thomas, ${ }^{b}$ Paul O’Brien* a b c and David J. \\ Lewis. ${ }^{\mathrm{bc}}$
}

\begin{abstract}
Polycrystalline thin films of chromium doped tungsten disulphide $\left(W_{2}\right)$ have been deposited onto glass and steel substrates by Aerosol-Assisted Chemical Vapour Deposition (AACVD) using bis(diethyldithiocarbamato)disulfidothioxo tungsten(VI) $\left(\mathrm{WS}_{3} \mathrm{~L}_{2}\right)$ and tris(diethyldithiocarbamato) chromium(III) $\left[\mathrm{Cr}\left(\mathrm{S}_{2} \mathrm{CNEt}_{2}\right)_{3}\right] \quad\left(\mathrm{CrL}_{3}\right)$ complexes as precursors in different molar ratios at $450{ }^{\circ} \mathrm{C}$. The deposited films were characterised by $\mathrm{p}$-XRD, SEM, EDX, and Raman spectroscopies. Chromium doping of up to 15 mol\% was achieved in $\mathrm{WS}_{2}$ thin films. The morphology of the doped films changed from lamellar for pure $\mathrm{WS}_{2}$ to florets in heavily doped material.
\end{abstract}

\section{Introduction}

Layered transition metal dichalcogenides (TMDs) such as tungsten disulfide $\left(W_{2}\right)$ and molybdenum disulfide $\left(\mathrm{MoS}_{2}\right)$ have attracted much attention due to several applications in photoelectrochemical (PEC) and photovoltaic (PV) cells, dry electrodes for batteries, gas sensors, and catalytic activity. ${ }^{1-8}$ They are also often used as a dry lubricant in mechanical systems. ${ }^{9-11}$ The excellent lubricating behavior is because of the layered crystal structure, in which a central layer atom is formed from tungsten between two layers of sulfur atoms. ${ }^{12,13}$ Weak non-covalent forces hold the layers together, so shearing of the crystal is easy in the lateral dimension.

A number of deposition techniques have been used to grow tungsten disulfide $\left(W_{2}\right)$ films which include atomic layer deposition (ALD), ion beam deposition, sputtering deposition and pulsed laser deposition and chemical vapour deposition. ${ }^{14-17}$ We have used aerosol assisted chemical vapor deposition (AACVD) $)^{18,19}$ for the growth of $\mathrm{MoS}_{2}$ films onto glass substrates from single source precursors. ${ }^{20}$ The stoichiometry of metal and ligand composition is easy to control using single source precursors. It is also easy to choose the decomposition temperature by informed precursor design and

\footnotetext{
a. School of Chemistry, University of Manchester, Oxford Road, Manchester M13 9PL, United Kingdom.

${ }^{b .}$ School of Materials, University of Manchester, Oxford Road, Manchester M13 9PL, United Kingdom.

International Centre for Advanced Materials (ICAM, Manchester Hub), University of Manchester, Oxford Road, Manchester M13 9PL, United Kingdom.

d. BP America, Incorporated, 501 Westlake Park Boulevard, Houston, Texas 77079, United States.
}

minimizes the use of toxic gases. ${ }^{21}$ Yongfeng et al. have reported the deposition of tungsten disulfide films by atomic layer deposition (ALD) technique using $W(C O)_{6}$ and $\mathrm{H}_{2} \mathrm{~S}$ as precursors. ${ }^{22}$ Zhu et al. deposited $\mathrm{WS}_{2}$ films on AISI 1045 steel by magnetron sputtering followed by ion sulfuration and was performed at low temperature to obtain a $\mathrm{WS}_{2}$ composite film which showed a superior hardness, elastic modulus and tribological properties compared to other samples prepared by the same method. ${ }^{23}$ Zafer et al. reported the deposition of a $\mathrm{WS}_{2}$ film by an e-beam deposition method. They deposited the $\mathrm{W}$ film onto $\mathrm{SiO}_{2}$ substrate then annealed and finally sulfurization of $\mathrm{W}$ film was performed to get the $\mathrm{WS}_{2}$ film. They studied the etching behavior of the $W_{2}$ film into a series of triangular shaped pits while heating in the air. The triangular pits increase with the increase in the number of layers of tungsten disulfide film. ${ }^{24}$

It has been demonstrated in previous studies that the doping of metallic elements such as $\mathrm{Cr}, \mathrm{Cu}, \mathrm{Ag}, \mathrm{Ti}$ into $\mathrm{WS}_{2}$ films may improve the hardness, adhesion and wear resistance of the films. ${ }^{25-29}$ The doping of nonmetallic elements such as $\mathrm{C}$ or $\mathrm{N}$ also helps to improve wear resistance properties, hardness, and adhesion of the film. ${ }^{30-33}$ Jhonattan et al. deposited titanium doped tungsten disulfide film onto AISI 304 stainless-steel substrates using the magnetron co-sputtering DC technique. $^{34}$ Petr et al. reported W-S-N coating deposited by d.c. reactive magnetron sputtering. They studied the effect of deposition conditions on chemical composition, morphology, tribological and mechanical properties. The hardness of the film deposited with a discharge pressure of $1.2 \mathrm{~Pa}$ increased with $\mathrm{N}$ content up to $7 \mathrm{GPa}$ and the coatings deposited at lower pressure show hardness around $9 \mathrm{GPa}^{35}$ Fredrik et al. 
deposited W-S-C-Cr and W-S-C-Ti coatings by magnetron sputtering they examined both systems and indicated significant amounts of oxides in the form of a layer just underneath the crystalline $\mathrm{WS}_{2}$ top layer. These coatings contained $40-50$ at\% $C$ but there was no carbon present in the tribofilms. They also observed that the $\mathrm{WS}_{2}$ basal plane is surrounded by Fe particles which show the chemical bonding between iron/steel and $\mathrm{WS}_{2}{ }^{36}$

Herein we report the deposition of $\mathrm{Cr}$-doped tungsten disulfide $\left(\mathrm{WS}_{2}\right)$ thin films onto glass and steel substrates by AACVD from the bis(diethyldithiocarbamato)disulfido, thioxo, tungsten(VI) and tris(diethyldithiocarbamato)chromium (III) complexes as a single source precursor. Such films have not been deposited before by AACVD and this work is the first example of CVD of a series of heavily doped $\mathrm{WS}_{2}$ films on glass and ferrous substrates.

\section{Experimental}

\section{Chemicals}

All reagents were purchased from Sigma-Aldrich and used without further purification, ammonium tetrathiotungstate $\left[\left(\mathrm{NH}_{4}\right)_{2} \mathrm{WS}_{4}\right] \quad(99.9 \%)$, sodium diethyldithiocarbamate trihydrate $\mathrm{NaS}_{2} \mathrm{CN}\left(\mathrm{C}_{2} \mathrm{H}_{5}\right)_{2} \cdot 3 \mathrm{H}_{2} \mathrm{O}$ $(\geq 95 \%)$ and chromium trichloride hexahydrate $\left(\mathrm{CrCl}_{3} \cdot 6 \mathrm{H}_{2} \mathrm{O}\right)(\geq 98 \%)$. Solvents were purchased from Sigma-Aldrich or Fisher acetone (99.0\%) dichloromethane $(\geq 99.8 \%)$, methanol (99.5\%), Hydrochloric acid ( $\mathrm{HCl})(37 \%)$.

\section{Instrumentation}

Elemental analysis and thermogravimetric analysis (TGA) with a heating rate of $10^{\circ} \mathrm{C} / \mathrm{min}$ under nitrogen from 30 ${ }^{\circ} \mathrm{C}$ to $600{ }^{\circ} \mathrm{C}$ of the precursors were performed by the University of Manchester, School of Chemistry microanalytical laboratory. Powder X-ray diffraction ( $p-X R D)$ was performed using Bruker D8 Advance diffractometer. All the samples were scanned between $10^{\circ}$ to $80^{\circ}$ using CuK $\alpha$ radiation (wavelength $1.5406 \AA$ ) an increment of $0.02^{\circ}$ and thedwell time was 3 seconds for every sample. Infrared spectra were recorded on a Specac single reflectance ATR instrument $\left(4000-400 \mathrm{~cm}^{-1}\right.$, resolution 4 $\mathrm{cm}^{-1}$ ). Scanning Electron Microscopy (SEM) was carried out using a Philips XL-30 FEG microscope. Energydispersive X-ray (EDX) spectroscopy was performed with a Philips EDAX DX4 X-ray micro-analyser SEM.

XPS measurements were carried out using a custom built Specs ${ }^{\mathrm{TM}} \mathrm{X}$-ray photoelectron spectrometer, equipped with a microfocused monochromated Al ka Xray source ( $\mathrm{hn}=1486.6 \mathrm{eV}$ ) and $150 \mathrm{~mm}$ Phoibos hemispherical analyser. The base pressure in the analysis chamber was around $1 \times 10^{-9}$ mbar during the measurements. $\mathrm{WS}_{2}$ films were presented on glass and steel substrates. Spectra are aligned on the binding energy scale relative to the adventitious hydrocarbon $C$ 1s signal at $284.8 \mathrm{eV} .^{37}$ Peak fitting was performed using the CASA XPS software using a linear background subtraction and a 70:30 Gaussian:Lorentzian mixd peak shape.

\section{Synthesis of bis(diethyldithiocarbamato)disulfido, thioxo, tungsten(VI) $\left[\mathrm{WS}_{3}\left(\mathrm{~S}_{2} \mathrm{CNEt}_{2}\right)_{2}\right]\left(\mathrm{WS}_{3} \mathrm{~L}_{2}\right)$}

$W_{3} L_{2}$ was synthesised as previously reported: ${ }^{38}$ briefly, an aqueous solution (300 $\mathrm{mL})$ of ammonium tetrathiotungstate $(2.91 \mathrm{~g}, 8.3 \mathrm{mmol})$ and sodium diethyldithiocarbamate trihydrate $(7.6 \mathrm{~g}, 33.8 \mathrm{mmol})$ was vigorously stirred with dropwise addition of $2 \mathrm{M} \mathrm{HCl}$ solution until a $\mathrm{pH}$ of 2 was obtained. Initially, yellow colored precipitates were produced which finally turns dark green with continued $\mathrm{HCl}$ addition. The mixture was stirred for 30 minutes. The precipitates were filtered by vacuum and washed with water $(3 \times 100 \mathrm{~mL})$ and dried in a vacuum oven at room temperature for an hour. The crude product was dissolved in acetone (250 $\mathrm{mL}$ ), filtered and the precipitates washed with acetone $(3 \times 40 \mathrm{~mL})$ to give a dark green solution and an orangebrown powder. The green solution was stripped of its solvent by evaporation before drying in a vacuum oven to give $\mathrm{WS}_{3} \mathrm{~L}_{2}$ as a dark green powder ( $2.53 \mathrm{~g}, 52.5 \%$ ). In addition, the orange-brown powder was dried in a high vacuum to give pure $W_{4} S_{4} L_{2}(0.99 \mathrm{~g}, 1.25 \mathrm{mmol}, 20.9$ $\%)$. The unit cell of $\mathrm{WS}_{2}$ and chemical structures of the precursors are shown in Fig. 1. FT-IR (solid), $v_{\max } / \mathrm{cm}^{-1}$ : 1511 (C-N), 997 ( $C=S$ ). Anal. calcd for $\mathrm{C}_{10} \mathrm{H}_{20} \mathrm{~N}_{2} \mathrm{~S}_{7} \mathrm{~W}$ : C, 20.86; H, 3.50; N, 4.86; S, 38.86 \%. Found: C, 21.00; $H$, $3.63 ; \mathrm{N}, 4.78 ; \mathrm{S}, 38.06$.

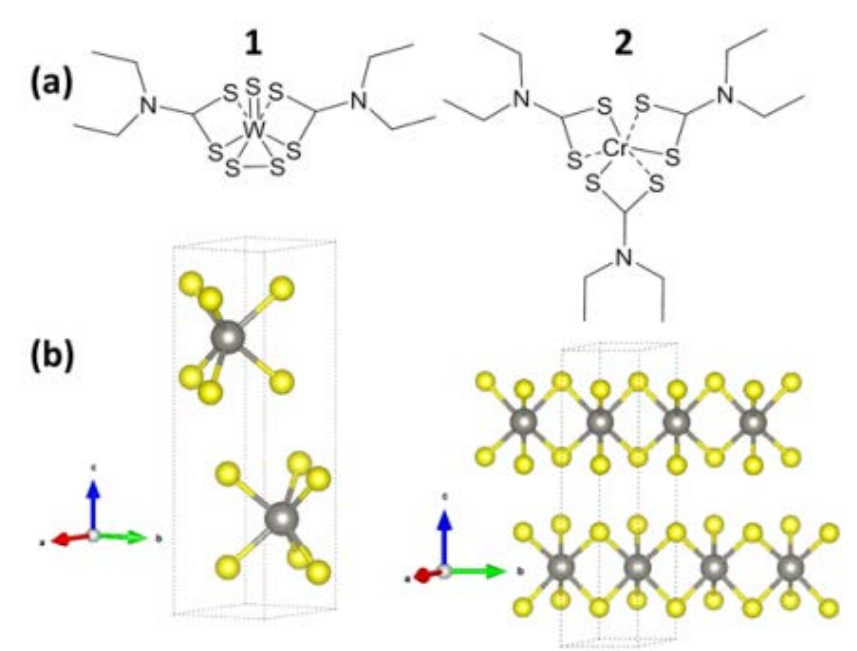

Fig. 1 (a) chemical structures of the precursors used in this study: $\left[\mathrm{WS}_{3}\left(\mathrm{~S}_{2} \mathrm{CNEt}_{2}\right)_{2}\right]$ (1), and $\left[\mathrm{Cr}\left(\mathrm{S}_{2} \mathrm{CNEt}_{2}\right)_{3}\right]$ (2). (b) structure of $\mathrm{WS}_{2}$ with the hexagonal unit cell marked $(\mathrm{a}=\mathrm{b}=$ $3.1532 \AA, c=12.232 \AA$ with $\left.\alpha=\beta=90^{\circ}, \quad \gamma=120^{\circ}\right)$, after Schutte. ${ }^{39}$ Gray atoms represent $\mathrm{W}$ and yellow atoms are $\mathrm{S}$. 


\section{Synthesis of tris(diethyldithiocarbamato)chromium (III) $\left[\mathrm{Cr}\left(\mathrm{S}_{2} \mathrm{CNEt}_{2}\right)_{3}\right]\left(\mathrm{CrL}_{3}\right)$}

The complex was synthesized by the literature method. ${ }^{8}$ Briefly, chromium trichloride hexahydrate $(4.0 \mathrm{~g}, 18$ mmol) was dissolved in water $(250 \mathrm{~mL})$. Concentrated hydrochloric acid was added to adjust the $\mathrm{pH}$ to 5 . The acidic green solution of chromium trichloride hexahydrate was added dropwise to the aqueous solution of monosodium salt of diethyl dithiocarbamate $(12.0 \mathrm{~g}, 54 \mathrm{mmol})$. The colour of the reaction mixture was changed to blue. These blue precipitates were removed by filtration and dried at room temperature in a vacuum oven. Column chromatography was used to purify the chromium complex. The bright blue band at the solvent front was collected. The solvent (dichloromethane) was removed under vacuum to obtain the pure product $(1.2 \mathrm{~g}, 13 \%) ; \mathrm{mp}, 260-261{ }^{\circ} \mathrm{C}$ FT-IR (solid) $v_{\max } / \mathrm{cm}^{-1}: 2975(\mathrm{w}), 2930(\mathrm{w}), 1491(\mathrm{~m})$ $1460(\mathrm{~m}), 1450(\mathrm{~m}), 1433(\mathrm{~m}), 1376(\mathrm{~m}), 1356(\mathrm{~m}), 1269$ $(\mathrm{m}), 1208(\mathrm{~m}), 1144(\mathrm{~m}), 1098(\mathrm{~m}), 1074(\mathrm{~m}), 995(\mathrm{~m})$. Anal. Calc for $\mathrm{C}_{15} \mathrm{H}_{30} \mathrm{~N}_{3} \mathrm{~S}_{6} \mathrm{Cr}$ : C, 36.27; $\mathrm{H}, 6.09 ; \mathrm{N}, 8.46 \%$. Found: $\mathrm{C}, 37.10 ; \mathrm{H}, 6.03 ; \mathrm{N}, 8.30 \%$.

\section{Aerosol-Assisted Chemical Vapor Deposition (AACVD)}

The glass and X65 steel substrates were thoroughly washed with acetone to remove any contamination and used for the deposition of thin films. In a typical deposition, $0.2 \mathrm{~g}(0.35 \mathrm{mmol})$ of total precursors $\left(\mathrm{WS}_{3} \mathrm{~L}_{2}\right.$ and $\mathrm{CrL}_{3}$ ) was dissolved in $25 \mathrm{ml}$ of tetrahydrofuran (THF) in a two-necked $100 \mathrm{ml}$ round-bottomed flask with a gas inlet. The solution was held over a piezoelectric humidifier and the aerosol thus created was carried by a stream of argon (180-200 $\mathrm{cm}^{3} \mathrm{~min}^{-1}$ ) into a quartz tube containing glass and steel substrates. The argon flow rate was controlled by a Platon flow gauge. The reactor tube was placed in a Carbolite furnace set at $450{ }^{\circ} \mathrm{C}$. The deposition of metal chalcogenides onto glass and steel substrates was continued for $90-100 \mathrm{~min}$ in all experiments.

\section{Results and discussion}

\section{Thermogravimetric Analysis}

Thermogravimetric analyses (TGA) of the precursor $\mathrm{CrL}_{3}$ shows single step decomposition while $W_{3} L_{2}$ shows four step decomposition (Fig. 2), at 133.50, 197.08, 319.71 and $\quad 394.13^{\circ} \mathrm{C}$ which correspond to weight loss of $10.7 \%, 16.7 \%, 7.79 \%$ and $7.84 \%$ respectively with a total weight loss of $43.0 \%$. The theoretically calculated weight loss for the formation of pure $\mathrm{WS}_{2}$ is $57.0 \%$. Marks et al. have proposed that the small difference between calculated and theoretical weight loss is due to residue in the TGA analysis of transition metal dithiocarbamate complexes. ${ }^{40}$ The stepwise decomposition of dithiocarbamate complexes have been previously observed, with EtSH, EtNCS, $\mathrm{CS}_{2}$, and $\mathrm{H}_{2} \mathrm{~S}$ expected as the volatile by-products. ${ }^{40-43}$ TGA of $\mathrm{WS}_{3} \mathrm{~L}_{2}$ shows rapid, initial decomposition which possibly forms $\mathrm{WS}_{2}\left(\mathrm{~S}_{2} \mathrm{CNEt}_{2}\right)$ and the remaining dithiocarbamate slow down the further growth of $W_{2}$ by terminating the reactive edge sites of $W_{2}$ where growth occurs most rapidly. $^{44,45}$

\section{Deposition of $\mathrm{Cr}$-doped $\mathrm{WS}_{2}$ thin films by AACVD}

The temperature chosen for deposition of materials by AACVD was $450{ }^{\circ} \mathrm{C}$ as both precursors are completely decomposed to the metal chalcogenide products by inspection of the TGA trace (Fig. 2). Deposition of tungsten disulfide $\left(\mathrm{WS}_{2}\right)$ and $\mathrm{Cr}$-doped $\mathrm{WS}_{2}$ films was performed by AACVD. The molar ratio of precursor

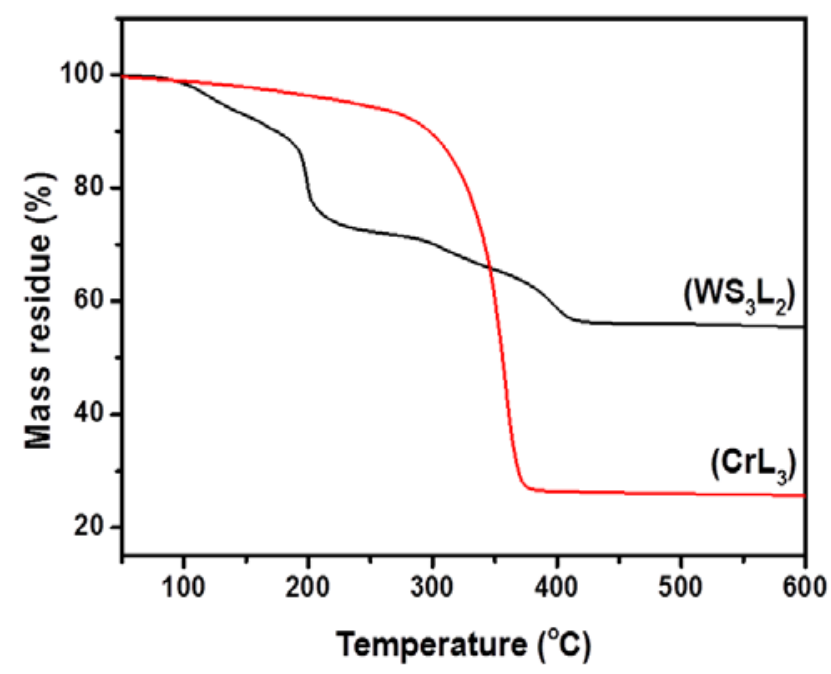

Fig. 2 TGA of $\left[\mathrm{WS}_{3}\left(\mathrm{~S}_{2} \mathrm{CNEt}_{2}\right)_{2}\right]\left(\mathrm{WS}_{3} \mathrm{~L}_{2}\right)$ and $\left[\mathrm{Cr}\left(\mathrm{S}_{2} \mathrm{CNEt}_{2}\right)_{3}\right]\left(\mathrm{CrL}_{3}\right)$ complexes

$\mathrm{WS}_{3} \mathrm{~L}_{2}$ and $\mathrm{CrL}_{3}$ was changed to give $5 \%, 10 \%$ and $15 \%$ at $\%$ feeds. The deposited films were characterised by powder X-ray diffraction ( $p-X R D)$, scanning electron microscopy (SEM) and Raman and energy dispersive $X$ ray (EDX) spectroscopies.

\section{Raman Spectroscopy of thin films}




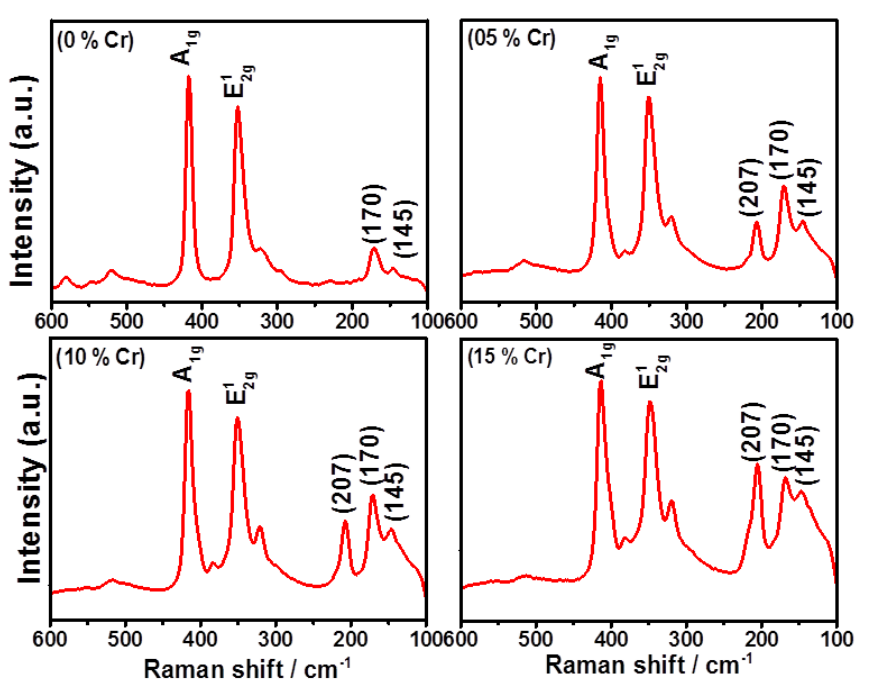

Fig. 3 Raman spectrum of of Cr-doped WS films deposited by AACVD onto glass substrates at $450^{\circ} \mathrm{C}$.

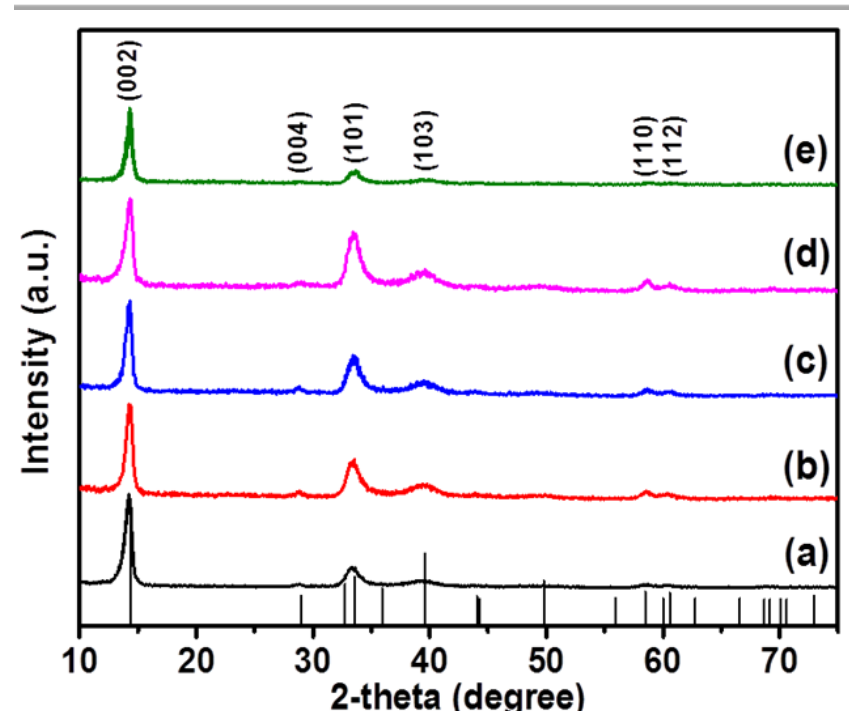

Fig. $5 \mathrm{p}$-XRD patterns of thin films deposited onto glass substrates by AACVD from $\left[\mathrm{WS}_{3}\left(\mathrm{~S}_{2} \mathrm{CNEt}_{2}\right)_{2}\right]$ at $450{ }^{\circ} \mathrm{C}$ by AACVD. The standard pattern is tungsten sulfide, $\mathrm{WS}_{2}$ (ICDD No: 01-084-1398). p-XRD pattern (a) shows WS ${ }_{2}$ without Cr-doping (b) 5 at\% $\mathrm{Cr}$, (c) 10 at\% Cr, (d) 15 at\% and (e) 20 at\% Cr-doped into $\mathrm{WS}_{2}$.

Raman spectroscopy was used to study $\mathrm{W}_{1-\mathrm{x}} \mathrm{Cr}_{\mathrm{x}} \mathrm{S}_{2}$ films deposited onto glass and steel substrates. The pure $\mathrm{WS}_{2}$ film had two main bands observed at $418 \mathrm{~cm}^{-1}$ and 352 $\mathrm{cm}^{-1}$ corresponding to the $A_{1 \mathrm{~g}}$ and $\mathrm{E}^{1}{ }_{2 \mathrm{~g}}$ modes along with a small shift at $170 \mathrm{~cm}^{-1}$. The Raman spectra for the $\mathrm{Cr}$ doped $\mathrm{WS}_{2}$ films deposited onto glass are shown in Fig. 3. There was a significant change in Raman spectra observed with the increase of chromium in the films. The intensity of the band observed at $170 \mathrm{~cm}^{-1}$ increases with the increase of chromium. There was another shift appeared at $207 \mathrm{~cm}^{-1}$ which correspond to first-order longitudinal acoustic (LA) mode, was not present in pure $\mathrm{WS}_{2}$ film. Upon increasing the amount of chromium in the films deposited on steel substrate, the intensity of the LA(M) longitudinal acoustic mode at $207 \mathrm{~cm}^{-1}$ was enhanced. ${ }^{46}$ The Raman spectra for the $\mathrm{Cr}$-doped $\mathrm{WS}_{2}$

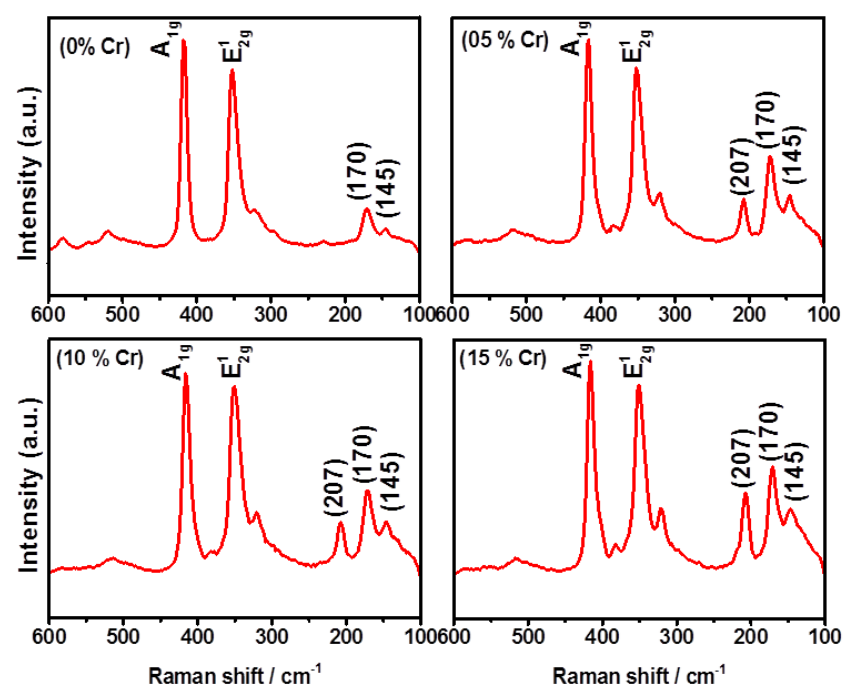

Fig. 4 Raman spectrum of of $\mathrm{Cr}$-doped $\mathrm{WS}_{2}$ films deposited by AACVD onto steel substrates at $450^{\circ} \mathrm{C}$.

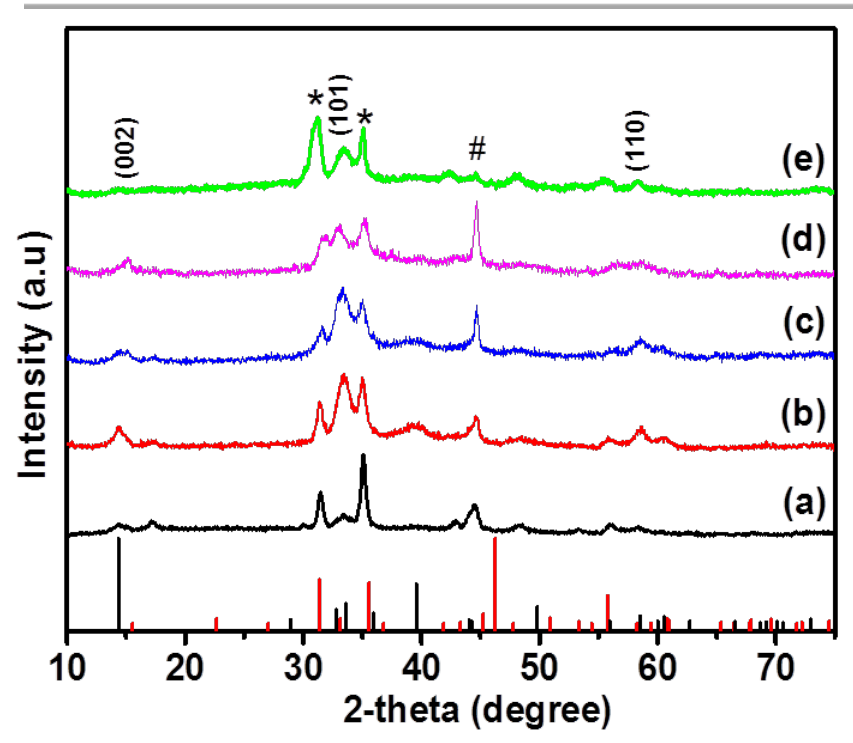

Fig. 6 p-XRD pattern of thin films deposited onto steel substrate from $\left[\mathrm{WS}_{3}\left(\mathrm{~S}_{2} \mathrm{CNEt}_{2}\right)_{2}\right]$ at $450{ }^{\circ} \mathrm{C}$ by AACVD. Black and red standard patterns show tungsten sulfide, WS 2 (ICDD No: 01-084-1398) and hexagonal iron sulfide, FeS (ICDD No: 01089-6272) respectively. p-XRD pattern (a) shows deposition of $\mathrm{WS}_{2}$ without $\mathrm{Cr}$ doping, (b) 5 at\% Cr, (c) 10 at\% Cr, (d) 15 at\% and (e) 20 at\% Cr-doped into WS 2 . The $\operatorname{star}\left({ }^{*}\right)$ and hash (\#) symbols represent the reflections from $\mathrm{FeS}$ and steel substrate respectively.

films deposited onto steel are shown in the Fig. 4. The Raman spectra for films deposited on steel substrate are same as films deposited on the glass substrate.

\section{Powder X-ray Diffraction (p-XRD)}

The $p$-XRD pattern of $W_{2}$ films deposited onto glass substrates showed two main reflections at $2 \theta=14.2^{\circ}$ for (002) plane and $2 \theta=33.5^{\circ}$ which is assigned to the (101) (Fig. 5). Hence the tungsten disulfide thin films deposited onto the glass substrate by AACVD have preferred orientation in the (002) plane. The $p-X R D$ 
patterns of $\mathrm{W}_{1-\mathrm{x}} \mathrm{Cr}_{\mathrm{x}} \mathrm{S}_{2}$ deposited onto glass substrate for the ratios 5, 10, 15 and 20 at\% $\mathrm{Cr}$ show the reflection at $2 \theta=14.24^{\circ}, 14.34^{\circ}, 14.36^{\circ}$ and $14.36^{\circ}$ respectively which can be assigned to the (002) and $2 \theta=33.5^{\circ}$ which is assigned to the (101) plane become more intense with the increase in molar ratio of $\mathrm{CrL}_{3}$ from 5 to 15 mole \%. However, the p-XRD pattern of the thin film with 20 at\% $\mathrm{Cr}$ shows comparatively weak reflection at $2 \theta=33.5^{\circ}$ for (101) which indicates the decrease in crystallinity with the increase in dopant. The graphical representations of the change in calculated $d$-spacing versus the amount of chromium found experimentally in the films show an almost linear dependence (Fig. 7). This suggests that the doping of chromium into the $\mathrm{WS}_{2}$ structure contracted the structure in the $z$-direction, pulling the layers of $\mathrm{WS}_{2}$ together. PXRD patterns of films grown on steel (Fig. 6) are markedly different in appearance compared to those grown on glass. We see the diffraction peaks from $\mathrm{WS}_{2}$ and steel, but also the pattern of a troilite subphase (FeS). Marks et al have also observed this phenomenon when growing $\mathrm{MoS}_{2}$ on steel, and it was attributed to an iron sulphide interphase between the steel substrate and the thin film, ${ }^{40}$ which leads to a seamless crystalline interface between thin film and substrate. This can also influence the morphology of the films produced (vide infra).

\section{SEM and Energy dispersive X-ray (EDX) Spectroscopy}

Energy dispersive X-ray (EDX) spectroscopy of the $W_{1}$ ${ }_{x} \mathrm{Cr}_{\mathrm{x}} \mathrm{S}_{2}$ thin films deposited by AACVD at $450{ }^{\circ} \mathrm{C}$ using mixtures of $W_{3} \mathrm{~L}_{2}$ and $\mathrm{CrL}_{3}$ showed a linear relationship between the mol\% of chromium in the feed solution and the mol\% of chromium found in the alloyed thin films (Fig. 8). The target composition and elemental composition found by EDX spectroscopy is given in the table $1 . \mathrm{W}$ and $\mathrm{S}$ were found in films generated from the decomposition of $\mathrm{WS}_{3} \mathrm{~L}_{2}$ alone, with ca. 33.38 at. \% W found in the film, close to the theoretical value of 33 at. $\% \mathrm{~W}$ in $\mathrm{WS}_{2}$. Other peaks observed include $\mathrm{Si}$ and $\mathrm{O}$ from glass substrates and $\mathrm{Fe}$ on

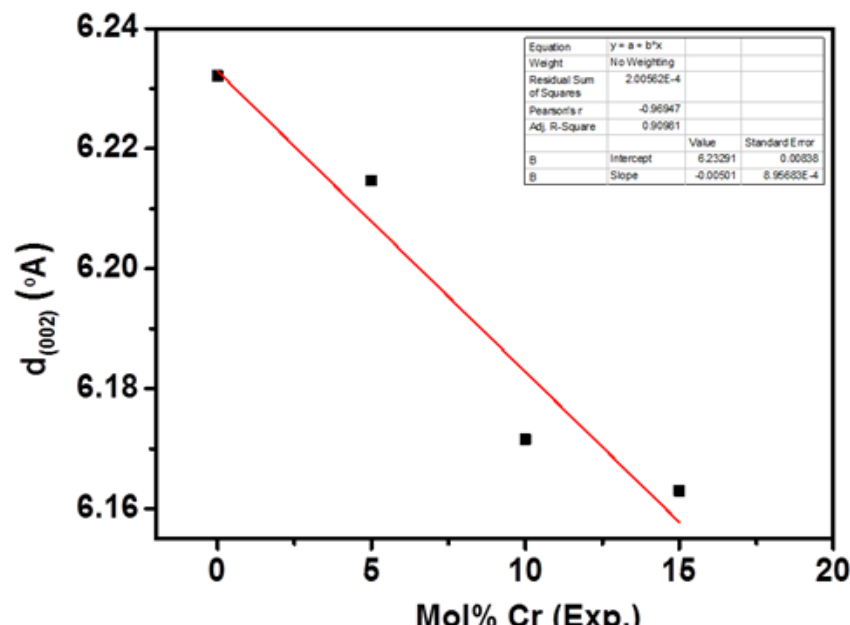

Fig. 7 Changes in d-spacing for the (002) plane in $\mathrm{WS}_{2}$ vs chromium dopant found experimentally using EDX spectroscopy for the deposition of $\mathrm{W}_{1-\mathrm{x}} \mathrm{Cr}_{\mathrm{x}} \mathrm{S}_{2}$ thin films onto glass substrates by AACVD at $450^{\circ} \mathrm{C}$ steel substrates.

Table 1 Results summary for the composition of $\mathrm{W}_{1-\mathrm{x}} \mathrm{Cr}_{\mathrm{X}} \mathrm{S}_{2}$ thin films as-measured by EDX spectroscopy.

\begin{tabular}{c|c|c|c}
\hline $\begin{array}{c}\text { Target } \\
\text { Composition }\end{array}$ & $\begin{array}{c}\text { Precursors } \\
\text { Ratio } \\
\text { (mmole) }\end{array}$ & $\begin{array}{c}\text { EDX results } \\
\text { (atomic \%) }\end{array}$ & $\begin{array}{c}\text { Alloy film } \\
\text { Stoichiometry }\end{array}$ \\
\hline$W_{2}$ & W: 0.350 & W: 33 & $\mathrm{~W}_{1.001} \mathrm{~S}_{1.999}$ \\
\hline
\end{tabular}

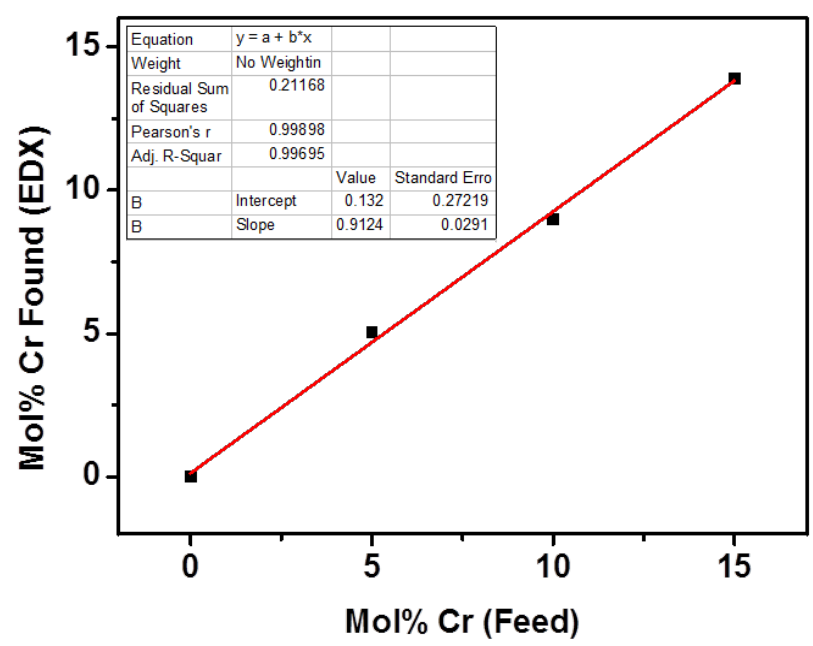

Fig. 8 Plot of mol\% $\mathrm{Cr}$ found by EDX spectroscopy in $\mathrm{W}_{1-x} \mathrm{Cr}_{x} \mathrm{~S}_{2}$ thin films deposited by AACVD at $450^{\circ} \mathrm{C}$ as a function of varying Mol\% of $\mathrm{Cr}$ in the AACVD feed.

\begin{tabular}{l|c|c|c} 
& $\mathrm{W}: 0.333$ & $\mathrm{~W}: 31$ & \\
$\mathrm{~W}_{0.95} \mathrm{Cr}_{0.05} \mathrm{~S}_{2}$ & $\mathrm{Cr}: 0.017$ & $\mathrm{~S}: 67$ & $\mathrm{~W}_{0.916} \mathrm{Cr}_{0.049} \mathrm{~S}_{2.035}$ \\
& & $\mathrm{Cr}: 0.6$ & \\
\hline & $\mathrm{W}: 0.315$ & $\mathrm{~W}: 33$ & \\
$\mathrm{~W}_{0.90} \mathrm{Cr}_{0.10} \mathrm{~S}_{2}$ & $\mathrm{Cr}: 0.035$ & $\mathrm{~S}: 64$ & $\mathrm{~W}_{0.988} \mathrm{Cr}_{0.097} \mathrm{~S}_{1.915}$ \\
& & $\mathrm{Cr}: 3.2$ & \\
\hline & $\mathrm{W}: 0.298$ & $\mathrm{~W}: 29$ & \\
$\mathrm{~W}_{0.85} \mathrm{Cr}_{0.15} \mathrm{~S}_{2}$ & $\mathrm{Cr}: 0.052$ & $\mathrm{~S}: 67$ & $\mathrm{~W}_{0.861} \mathrm{Cr}_{0.139} \mathrm{~S}_{2}$
\end{tabular}

The morphologies of $\mathrm{WS}_{2}$ and $\mathrm{Cr}$-doped $\mathrm{WS}_{2}$ thin films were imaged using secondary electron scanning electron microscopy (SE SEM). SE SEM images of the films deposited onto glass and steel substrate at $450{ }^{\circ} \mathrm{C}$ are shown in Fig. 9 and Fig. 10 respectively. The SE SEM images of the pure $\mathrm{WS}_{2}$ film deposited on glass substrate showed floret morphology while the film deposited with $5 \% \mathrm{Cr}$-doped showed orbicular shaped crystallites. The SEM images of $\mathrm{WS}_{2}$ thin films with 10 at\% $\mathrm{Cr}$-doped show triangular shape crystallites. Whereas the crystallites of the $\mathrm{WS}_{2}$ thin film with 15 at\% $\mathrm{Cr}$-doping show floret morphology. The crystallites of pure $\mathrm{WS}_{2}$ deposited onto steel substrate at $450{ }^{\circ} \mathrm{C}$ show lamellar morphology. The SEM images of $\mathrm{WS}_{2}$ films deposited with 5 at\%, 10 at\% and 15 at\% $\mathrm{Cr}$-doping show predominant growth of dense sheet-like crystallites. It is suspected that the major differences in morphology between films grown on 

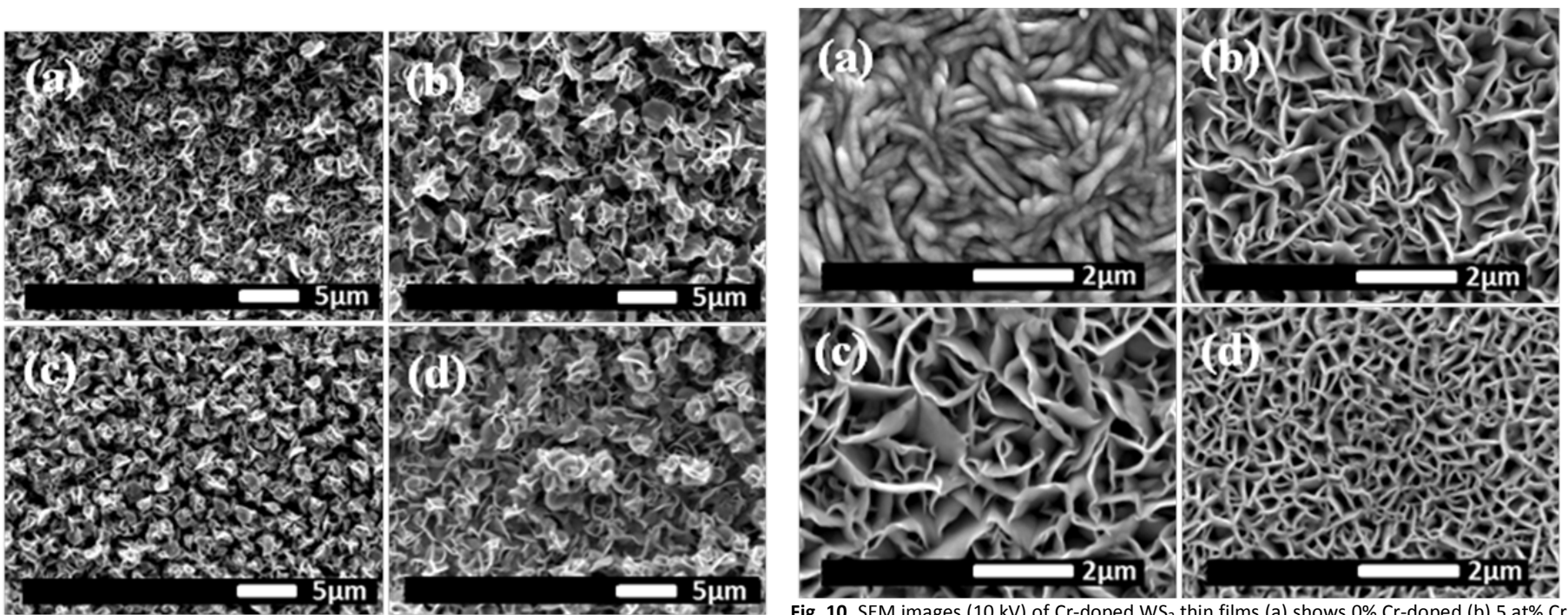

Fig. 10 SEM images (10 kV) of Cr-doped WS 2 thin films (a) shows $0 \% \mathrm{Cr}$-doped (b) 5 at $\% \mathrm{Cr}$ Fig. 9 SEM images ( $10 \mathrm{kV}$ ) of $\mathrm{Cr}_{\text {-doped }} \mathrm{WS}_{2}$ thin films (a) shows 0 at $\% \mathrm{Cr}$-doped (b) 5 at $\% \mathrm{Cr}$ (c) 10 at $\% \mathrm{Cr}$ and (d) shows 15 at\% $\mathrm{Cr}_{\text {-doped into }} \mathrm{WS}_{2}$ films deposited onto steel substrate (c) 10 at $\% \mathrm{Cr}$ and (d) shows 15 at\% $\mathrm{Cr}$-doped into $\mathrm{WS}_{2}$ films deposited onto glass substrate at $4500^{\circ} \mathrm{C}$ by AACVD.

at $450^{\circ} \mathrm{C}$ by AACVD.
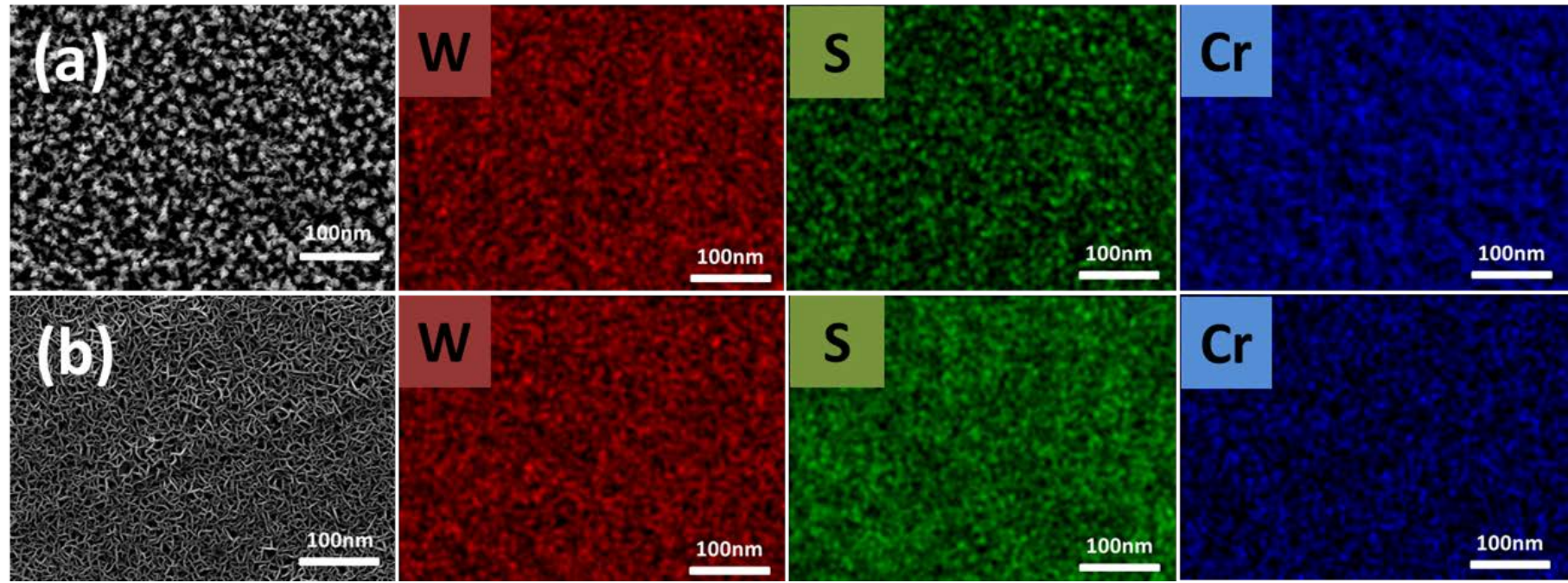

Fig. 11 EDX spectrum maps (20 kV) of $\mathrm{W} \mathrm{L} \alpha, \mathrm{Cr}$ K $\alpha$ and $\mathrm{S} \mathrm{K \alpha}$ emission in (a) 15 at\% $\mathrm{Cr}$-doped $\mathrm{WS}_{2}$ thin films deposited onto glass substrate and (b) onto steel substrate at $450{ }^{\circ} \mathrm{C}$ respectively.

steel and films grown on glass are due to the substrate influencing the growth of the crystalline inorganic thin film and this is presumably caused by growth of the $\mathrm{WS}_{2}$ phase over the FeS phase, as-observed in pXRD (vide supra).

EDX mapping of 15 at\% chromium doped $\mathrm{W}_{1-\mathrm{x}} \mathrm{Cr}_{x} \mathrm{~S}_{2}$ films deposited onto glass and steel substrate by AACVD at 450 ㅇ $\mathrm{C}$ (Fig. 11) demonstrated that in both cases $\mathrm{W}, \mathrm{Cr}$ and $\mathrm{S}$ are distributed uniformly throughout the film.

\section{X-Ray Photoelectron Spectroscopy (XPS)}

The survey spectra (Fig. 12) show the presence of $W$ and $S$ peaks for both films. Both samples show evidence of $C$ and $O$ contamination, most likely arising from adsorbed hydrocarbon contamination and adsorbed water/hydroxyl species. The glass mounted sample shows a significant amount of sodium contamination. The coated steel sample shows evidence of $\mathrm{Cu}$. Neither sample has $\mathrm{Cr}$ peaks in the topmost $10 \mathrm{~nm}$ of the surface, suggesting tungsten oxide is formed at the surface, burying the $\mathrm{Cr}$ below.

Detailed scans of the W $4 d$ and $S 2 p$ are shown in Fig.13 \& 14. The $\mathrm{Cu} 2 \mathrm{p}$ spectrum indicates two $\mathrm{Cu}$ species with 


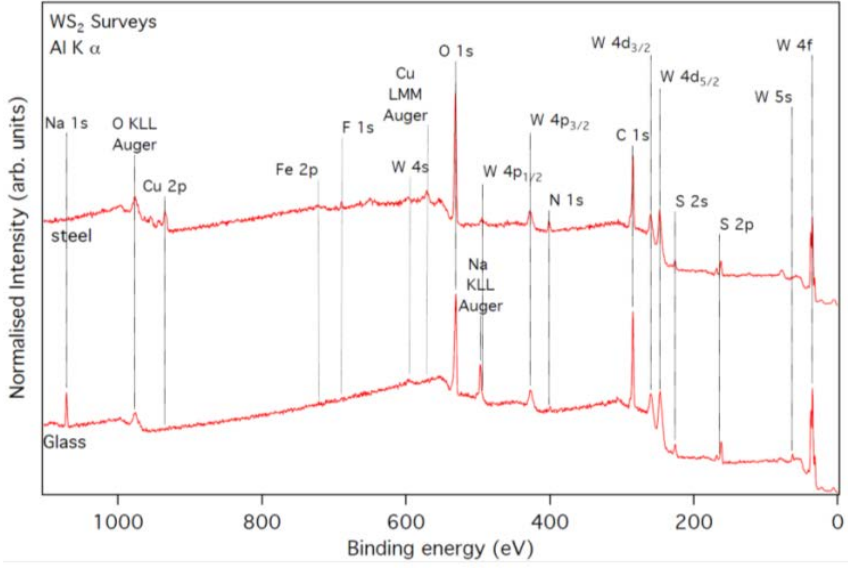

Fig. 12 The XPS surveys spectra of Cr-doped WS2 thin films deposited onto glass and steel substrate at $450^{\circ} \mathrm{C}$ by AACVD.

$\mathrm{Cu} 2 \mathrm{p}_{3 / 2}$ peaks at binding energies of 932.6 and $935.0 \mathrm{eV}$. The strong and complex satellite centred around a binding energy

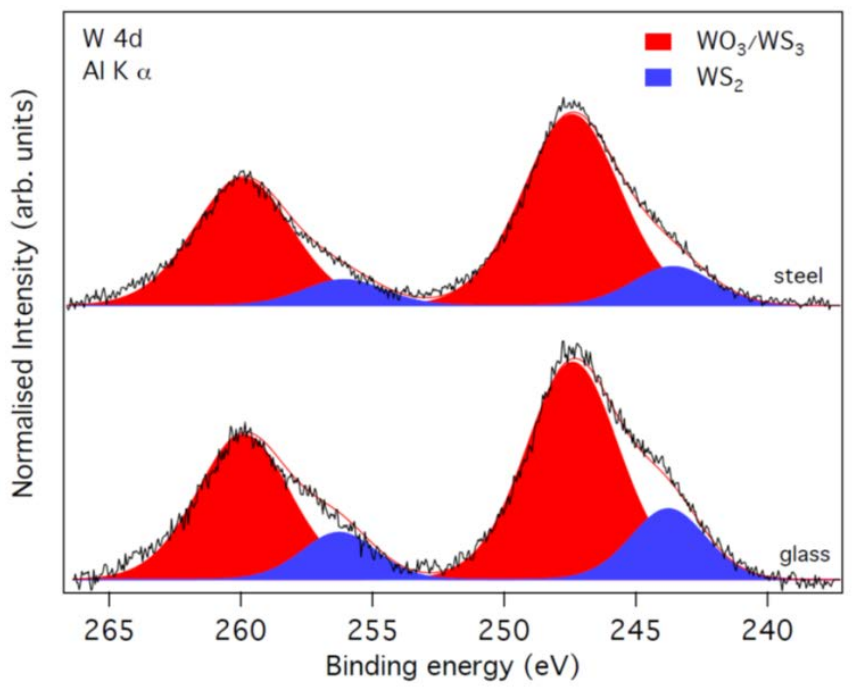

Fig. 13 Deconvoluted W 4d spectrum of thin films deposited onto glass and stee substrate by AACVD

of $942.6 \mathrm{eV}$ indicates that these $\mathrm{Cu}$ species are in in the $\mathrm{Cu}(\mathrm{II})$ oxidation state. The $\mathrm{Cu} 2 \mathrm{p}_{3 / 2}$ peak at the higher binding energy (B.E.) is consistent with $\mathrm{Cu}(\mathrm{II})$ hydroxide species ${ }^{47}$, and is consistent with the presence of the $O 1 \mathrm{~s}$ peak observed in the survey spectrum. The lower energy peak has a binding energy, which could be due to CuO or CuS species.

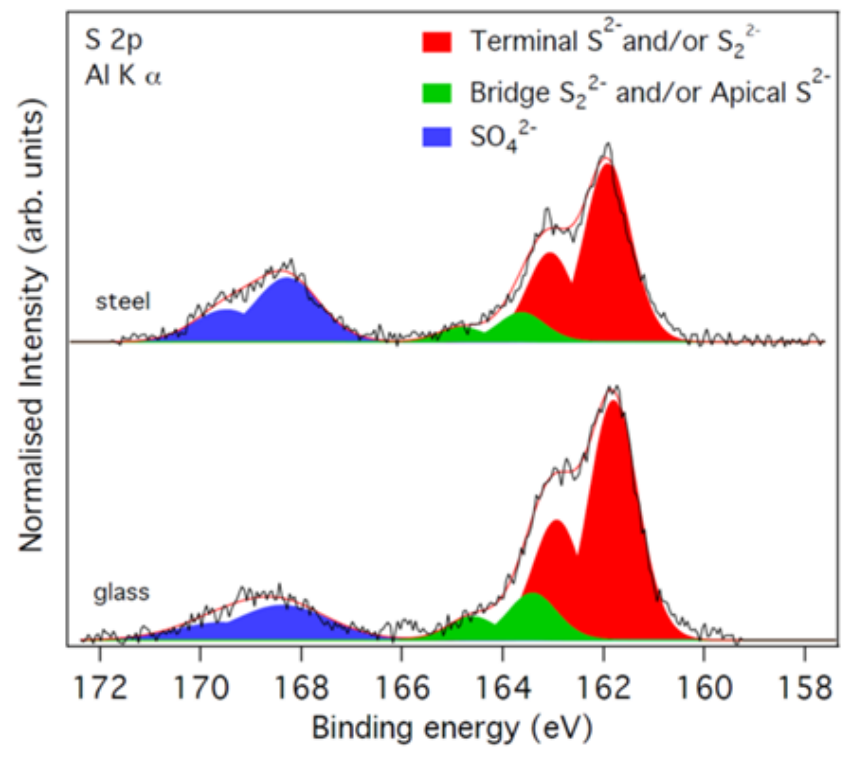

Fig.14 Deconvoluted S $2 p$ spectrum of thin films deposited onto glass and steel substrate by AACVD

The W 4d spectra show (Fig. 13) two sets of spin orbit doublets for the two films. The binding energies of the $\mathrm{W}$ $4 \mathrm{~d} 5 / 2$ of $243.7 \mathrm{eV}$ and $247.4 \mathrm{eV}$ are consistent with $\mathrm{WS}_{2}$ and $\mathrm{WO}_{3}$ species respectively [refs], suggesting significant oxidation of the films in the topmost surface region and supporting the suggestion that the $\mathrm{Cr}$ remains buried in the film.

S $2 p$ spectra (Fig. 14) can be fitted with three sets of spin orbit doublets in agreement with earlier work on $\mathrm{WS}_{2}$ and $\mathrm{MoS}_{2}$. These are consistent with the presence of sulfate ( $S$ $2 p_{3 / 2}$ B.E. $\left.=168.3 \mathrm{eV}\right)^{48}$, and terminal $\mathrm{S}^{2-}$ and/or $\mathrm{S}_{2}{ }^{2-}\left(\mathrm{S} 2 \mathrm{p}_{3 / 2}\right.$ B.E. $=162.0 \mathrm{eV})$ and bridging $\mathrm{S}_{2}{ }^{2-}$ and/or apical $\mathrm{S}^{2-}\left(\mathrm{S}_{2} 2 \mathrm{p}_{3 / 2}\right.$ B.E. $=163.4 \mathrm{eV}$ ) in the $\mathrm{WS}_{2}{ }^{49,50}$.

\section{Conclusions}

$\mathrm{WS}_{2}$ and $\mathrm{Cr}$-doped $\mathrm{W}_{1-\mathrm{x}} \mathrm{Cr}_{\mathrm{x}} \mathrm{S}_{2}$ thin films were deposited onto glass and steel substrates by AACVD using bis(diethyldithiocarbamato)disulfido, thioxo, tungsten(VI) $\left[\mathrm{WS}_{3}\left(\mathrm{~S}_{2} \mathrm{CNEt}_{2}\right)_{2}\right]$ and tris(diethyldithiocarbamato)chromium (III) $\left[\mathrm{Cr}\left(\mathrm{S}_{2} \mathrm{CNEt}_{2}\right)_{3}\right]$ complexes as precursors. Scanning electron microscopy (SEM) indicated that the morphology and the microstructure of the deposited thin films significantly changes with the addition of chromium as a dopant. The EDX spectroscopy confirmed the presence and composition of the dopant.

The powder x-ray diffraction patterns confirmed the films grown onto the glass substrate were highly crystalline and 
gave monophasic hexagonal $W_{2}$ whereas the films deposited onto the steel substrate produced a mixture of hexagonal tungsten sulfide $\left(\mathrm{WS}_{2}\right)$ and hexagonal Iron sulfide which is due to strong adhesion or a chemical bonding between iron/steel and $\mathrm{WS}_{2}$. The Raman spectroscopy also confirmed the presence of the chromium in $\mathrm{W}_{1-\mathrm{x}} \mathrm{Cr}_{\mathrm{X}} \mathrm{S}_{2}$ films.

In summary, this method affords excellent control over dopant concentration by using dual pre-cursors in the feed. The work reported herein is a very simple and inexpensive route for the deposition of $\mathrm{Cr}$-doped tungsten disulfide thin films which has the potential for scalability.

\section{Conflicts of interest}

There are no conflicts to declare.

\section{Acknowledgements}

This work was enabled by the award of a grant to POB and DJL from the BP International Centre for Advanced Materials (BP-ICAM). We would like to thank Dr. Benjamin Dennis-Smither (BP) for useful comments regarding the manuscript.

\section{Notes and references}

1. H. Tributsch, Zeitschrift für Naturforschung A, 1977, 32, 972-985.

2. H. Tributsch and J. Bennett, Journal of Electroanalytical Chemistry and Interfacial Electrochemistry, 1977, 81, 97111.

3. M. Regula, C. Ballif, J. Moser and F. Levy, Thin Solid Films, 1996, 280, 67-75.

4. W. Zhang, P. Zhang, Z. Su and G. Wei, Nanoscale, 2015, 7, 18364-18378.

5. P. K. Kannan, D. J. Late, H. Morgan and C. S. Rout, Nanoscale, 2015, 7, 13293-13312.

6. T. F. Jaramillo, K. P. Jørgensen, J. Bonde, J. H. Nielsen, S. Horch and I. Chorkendorff, science, 2007, 317, 100-102.

7. J.-H. Cha, S.-J. Choi, S. Yu and I.-D. Kim, Journal of Materials Chemistry A, 2017, 5, 8725-8732.

8. D. J. Lewis, A. A. Tedstone, X. L. Zhong, E. A. Lewis, A. Rooney, N. Savjani, J. R. Brent, S. J. Haigh, M. G. Burke and C. A. Muryn, Chemistry of Materials, 2015, 27, 1367-1374.

9. Y. $\mathrm{Xu}, \mathrm{E} . \mathrm{Hu}, \mathrm{K} . \mathrm{Hu}, \mathrm{Y} . \mathrm{Xu}$ and X. Hu, Tribology International, 2015, 92, 172-183.

10. H. Huang, J. Tu, L. Gan and C. Li, Wear, 2006, 261, 140144.

11. S. Prasad and J. Zabinski, Nature, 1997, 387, 761.

12. R. G. Dickinson and L. Pauling, Journal of the American Chemical Society, 1923, 45, 1466-1471.

13. Y. Sang, Z. Zhao, M. Zhao, P. Hao, Y. Leng and H. Liu, Advanced Materials, 2015, 27, 363-369.
14. H. Wu, R. Yang, B. Song, Q. Han, J. Li, Y. Zhang, Y. Fang, R. Tenne and C. Wang, ACS nano, 2011, 5, 1276-1281.

15. H. Samassekou, A. Alkabsh, M. Wasala, M. Eaton, A. Walber, A. Walker, O. Pitkänen, K. Kordas, S. Talapatra and T. Jayasekera, 2D Materials, 2017, 4, 021002.

16. G. Danda, P. Masih Das, Y.-C. Chou, J. T. Mlack, W. M. Parkin, C. H. Naylor, K. Fujisawa, T. Zhang, L. B. Fulton and M. Terrones, ACS nano, 2017, 11, 1937-1945.

17. Y. Wang, Y. Bai, J. Xi, M. Liu, M. Li, K. Hong and Y. Sun, Materials Letters, 2017.

18. M. Lazell, P. O'Brien, D. J. Otway and J.-H. Park, Journal of the Chemical Society, Dalton Transactions, 2000, 44794486.

19. P. Marchand, I. A. Hassan, I. P. Parkin and C. J. Carmalt, Dalton Transactions, 2013, 42, 9406-9422.

20. A. Adeogun, M. Afzaal and P. O'Brien, Chemical Vapor Deposition, 2006, 12, 597-599.

21. M. A. Malik, M. Afzaal and P. O'Brien, Chemical reviews, 2010, 110, 4417-4446.

22. Y. Sun, Z. Chai, X. Lu and J. Lu, Tribology International, 2017, 114, 478-484.

23. Z. Li-Na, W. Cheng-Biao, W. Hai-Dou, X. Bin-Shi, Z. DaMing, L. Jia-Jun and L. Guo-Lu, Vacuum, 2010, 85, 16-21.

24. Z. Mutlu, M. Ozkan and C. S. Ozkan, Materials Chemistry and Physics, 2016, 176, 52-57.

25. B. Deepthi, H. C. Barshilia, K. Rajam, M. S. Konchady, D. M. Pai, J. Sankar and A. V. Kvit, Surface and Coatings Technology, 2010, 205, 565-574.

26. X. Zheng, J. Tu, D. Lai, S. Peng, B. Gu and S. Hu, Thin Solid Films, 2008, 516, 5404-5408.

27. Q. Wang, J. Tu, S. Zhang, D. Lai, S. Peng and B. Gu, Surface and Coatings Technology, 2006, 201, 1666-1670.

28. S. Xu, X. Gao, M. Hu, D. Wang, D. Jiang, J. Sun, F. Zhou, L. Weng and W. Liu, Tribology Letters, 2014, 55, 1-13.

29. T. Scharf, A. Rajendran, R. Banerjee and F. Sequeda, Thin Solid Films, 2009, 517, 5666-5675.

30. A. Nossa and A. Cavaleiro, Surface and Coatings Technology, 2003, 163, 552-560.

31. A. Nossa and A. Cavaleiro, Surface and Coatings Technology, 2001, 142, 984-991.

32. M. Evaristo, A. Nossa and A. Cavaleiro, Surface and Coatings Technology, 2005, 200, 1076-1079.

33. T. Polcar, M. Evaristo and A. Cavaleiro, Plasma Processes and Polymers, 2007, 4.

34. J. D. L. Roche, J. M. Gonzalez, E. R. Parra and F. Sequeda, Matéria (Rio de Janeiro), 2016, 21, 461-469.

35. P. Mutafov, M. Evaristo, A. Cavaleiro and T. Polcar, Surface and Coatings Technology, 2015, 261, 7-14.

36. F. Gustavsson, M. Bugnet, T. Polcar, A. Cavaleiro and S. Jacobson, Tribology Transactions, 2015, 58, 113-118.

37. T. L. Barr and S. Seal, Journal of Vacuum Science \& Technology A: Vacuum, Surfaces, and Films, 1995, 13, 1239-1246.

38. A. A. Tedstone, E. A. Lewis, N. Savjani, X. L. Zhong, S. J. Haigh, P. O'Brien and D. J. Lewis, Chemistry of Materials, 2017, 29, 3858-3862.

39. W. Schutte, J. De Boer and F. Jellinek, Journal of Solid State Chemistry, 1987, 70, 207-209.

40. M. N. McCain, B. He, J. Sanati, Q. J. Wang and T. J. Marks, Chemistry of Materials, 2008, 20, 5438-5443.

41. P. C. Mitchell, Wear, 1984, 100, 281-300. 
42. N. Savjani, J. R. Brent and P. O'Brien, Chemical Vapor Deposition, 2015, 21, 71-77.

43. M. Azad Malik, Journal of Materials Chemistry, 1999, 9, 2433-2437.

44. J.-W. Chung, Z. Dai and F. Ohuchi, Journal of crystal growth, 1998, 186, 137-150.

45. N. E. Richey, C. Haines, J. L. Tami and L. McElwee-White, Chemical Communications, 2017.

46. H. Li, Q. Zhang, C. C. R. Yap, B. K. Tay, T. H. T. Edwin, A. Olivier and D. Baillargeat, Advanced Functional Materials, 2012, 22, 1385-1390.

47. M. C. Biesinger, Surface and Interface Analysis, 2017, 49, 1325-1334.

48. A. A. Audi and P. M. Sherwood, Surface and Interface Analysis: An International Journal devoted to the development and application of techniques for the analysis of surfaces, interfaces and thin films, 2000, 29, 265-275.

49. T. Wang, J. Zhuo, K. Du, B. Chen, Z. Zhu, Y. Shao and M. Li, Advanced Materials, 2014, 26, 3761-3766.

50. G. Huang, H. Liu, S. Wang, X. Yang, B. Liu, H. Chen and M. $\mathrm{Xu}$, Journal of Materials Chemistry A, 2015, 3, 2412824138. 